\title{
E-læring - teknologiens muligheder og perspektiver
}

\author{
Rasmus Blok \\ PhD-stipendiat \\ Inst. for Æstetiske Fag \\ Aarhus Universitet \\ litrb@hum.au.dk \\ http://www.rasmusblok.dk
}

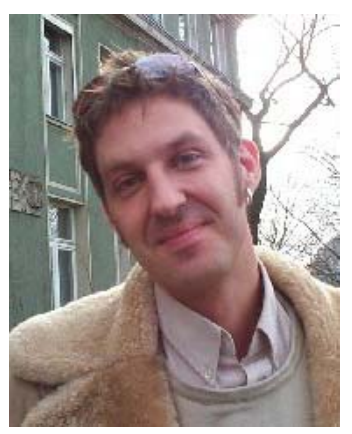

Rasmus Blok er PhD-stipendiat ved Inst. for Astetiske Fag, Afd. for Litteraturhistorie og ved Multimedieuddannelsen, Aarhus Universitet. Han arbejder til dagligt med forskning i digital litteratur og kultur, men har i sine tidligere anscettelser og som en speciel didaktisk anskuelse på sin egen forskning $i$ en loengere årrcekke arbejdet med e-loering ud fra et praktisk, poedagogisk og organisationsmoessigt udviklingsperspektiv. Han har udviklet kurser, kursusmaterialer, guider, strategier og skrevet artikler i relation til e-loeringen ved Aarhus Universitet, og arbejder $i$ øjeblikket på fcerdiggørelsen af en indførende bog om det praktiske, poedagogiske og organisatoriske arbejde med e-loering. Yderligere information kan hentes på Internetsiden: www.rasmusblok.dk

\section{Introduktion}

Den teknologi som muliggør e-læringen er de computermedierede konferencer eller $C M C$ som den ofte også omtales. Her i forståelsen Computer Mediated Conferencing, ikke at forveksle med det beslægtede Computer Mediated Communication. I det følgende vil CMC derfor referere til de computermedierede konferencer. Nogen vil måske hævde, at e-læring er et bredt begreb, der kan betegne et vidt spekter af forskellige konstellationer og brug af IKT i undervisningen. Men der er stor forskel på om man benytter en computer som objekt eller som redskab for undervisningen, ligesom der er stor forskel på om computeren benyttes som et redskab blandt andre i undervisningssituationen eller om undervisningen baserer sig på computeren som altafgørende værktøj. Om end de ofte er blevet mudret sammen, så er der afgørende forskel på undervisning om IKT og undervisning med IKT. E-læring er selvfølgelig ikke bundet til læring om IKT, men til læringen om alt muligt mellem himmel og jord med IKT, herunder selvfølgelig også IKT selv. Men læring med IKT skaber ikke nødvendigvis rammerne for e-læring. En computer som redskab i undervisningslokalet, som den studerende aktivt kan benytte i sin vidensopbygning, vidner om IKT i læringsmiljøet, men ikke nødvendigvis om e-læring, da denne efter min bedste overbevisning udelukkende må basere sig på computermediet.

E-læringen er i den optik derfor afgørende bundet til en computermediering og her indenfor en dialog- og konferencebaseret software, som kan skabe det virtuelle læringsmiljø og undervisningslokale, hvor indenfor e-læringen kan finde sted mellem underviser og studerende. I den henseende betyder det, at e-læring kun er mulig på baggrund af $C M C$ eller computermedieret konferencesoftware. Konferencesoftwaren kan dog have mange forskellige udformninger og enten være web-baseret eller intranet-baseret, evt. via et særligt klientprogram, med tilhørende speciel server-software. 
Udviklingen af $C M C$-systemerne betyder således at underviser og uddannelsesinstitutioner for første gang har fået et reelt alternativ til den traditionelle og ordinære undervisning ansigt til ansigt med de studerende. Imidlertid har mange blot anset e-læring som et sekundært alternativ eller som den "næstbedste løsning". Men mediet for e-læring har en række karakteristika, som på mange måder kan være med til at udvikle og forbedre læringsprocessen og tilvejebringe en række optimerede muligheder for kommunikation og undervisning. I samme åndedrag viser $C M C$ sig at være et vigtigt redskab til at håndtere og arbejde med de stigende krav og nye kompetencer, som fra samfundets side kræves af de studerende på mange niveauer. Her tænkes ikke blot på integrerede IKT-kompetencer, men også kompetencer indenfor samarbejde og udvikling, ansvar for egen læring og refleksion og kognition.

Studier af forholdet mellem e-læring via $C M C$ og den ordinære undervisning ansigt til ansigt viser, at underviseren i sidste tilfælde bibringer op omkring $80 \%$ af kommunikationen, mens det for e-læring kun er tale om 10-15\% (jf Learning Technology Support Service, http://www.ltss.bris.ac.uk/cmc 2.htm). Studerende via e-læring tager således i højere grad selv del i og ansvar for undervisningen. Atter andre undersøgelser viser at studerende modtagende undervisning gennem e-læring finder, at de i højere grad end i den ordinære undervisning, reflekterer over deres egne tanker og det de har lært. Deres metakognitive færdigheder så som selv-refleksion og læringsrevision er langt mere styrket gennem e-læringen end gennem undervisningen i klasseværelset og auditoriet. Hertil kommer selvfølgelig, at brug af $C M C$ er en oplagt, hvis ikke den absolut bedste vej til at give de studerende et integrerede kendskab til IKT.

Varieteten i udbuddet af $C M C$ gør imidlertid ikke, at kernen af softwaren til e-læringen varierer kraftigt, men blot at deres udseende kan være forskelligt. Dvs. at den grundlæggende funktionalitet af $C M C$ langt overvejende er den samme fra program til program og løsning til løsning, man møder. Denne artikels gennemgang af de computermedierede konferencer vil derfor være sigende for langt de fleste varianter af $C M C$. Men af praktiske grunde vil jeg kun referere til et enkelt program, nemlig FirstClass, som er det mest udbredte og benyttede $C M C$ system herhjemme, og det jeg har arbejdet og eksperimenteret med på Aarhus Universitet.

Nedenfor vil jeg således introducere til tekstbaserede computermedierede konferencer og beskrive en række af de fordele (og ulemper) benyttelsen af denne teknologi, efter min erfaring og viden, kan have for undervisningen. Samtidigt fokuser jeg på den særegne karakteristik, som kommunikationen via computermedierede konferencer iscenesætter og peger på forskellige tilgange til en fordelagtig benyttelse af den. Endelig vil der til sidst være et kort afsnit om de muligheder $C M C$ i øvrigt kan tilbyde uddannelsesinstitutionerne, når $C M C$ allerede benyttes til e-læring.

Det er vigtigt at bemærke, at nærværende introduktion til og karakteristik af e-læringen, baserer sig på en 100\% benyttelse af CMC-teknologien. Dvs. undervisning, som ren e-læring udelukkende via $C M C$. I almindelighed vil e-læringen til tider blive kombineret med en eller flere former for nærundervisning, fx konfrontationstimer, seminarer o. lign. Sådanne blandede undervisningsformer vil i betydelig grad dæmme op for nogle af de ulemper man kan opleve ved e-læring og i yderligere grad tilvejebringe fleksibilitet til undervisningen og læringen. Men for at kunne danne sig et klart billede af e-læringens pædagogiske muligheder og begrænsninger via $C M C$, må der tages udgangspunkt i en rene udnyttelse af teknologien.

\section{Hvad er CMC eller computermedierede konferencer?}

Computermedierede konferencer er en teknologi meget lig e-mailen, idet den fungerer ved at sende og modtage tekstbaserede meddelelser og fungerer asynkront. Det vil sige at deltagerne 
kan poste og læse meddelelserne på et hvilket som helst tidspunkt og fra et hvilket som helst sted i verden (med internet-opkobling), således at de er fri af enhver binding i tid og sted, der eller forekommer ved ordinær undervisning.

Modsat e-mailen tillader de computermedierede konferencer at man skaber bestemte fora hvor distinkte diskussioner kan finde sted, og meddelelserne deles. Dette tillader underviseren at konstruere 'klasseværelser' for sine deltagere hvori diskussioner og gruppedynamik kan plejes og en række læringsudvekslinger kan etableres. Via denne teknologi kan de studerende ikke blot kontakte deres underviser eller hinanden på en privat og individuel basis (lig emailen), men kan samtidigt også arbejde sammen i grupper, deles om opgaver, give hinanden respons, bidrage til åbne diskussioner og dele ressourcer og indsigt med hinanden. Og alt sammen noget der tidsmæssigt og stedmæssigt kan finde sted efter underviseren og/eller de studerendes ønske.

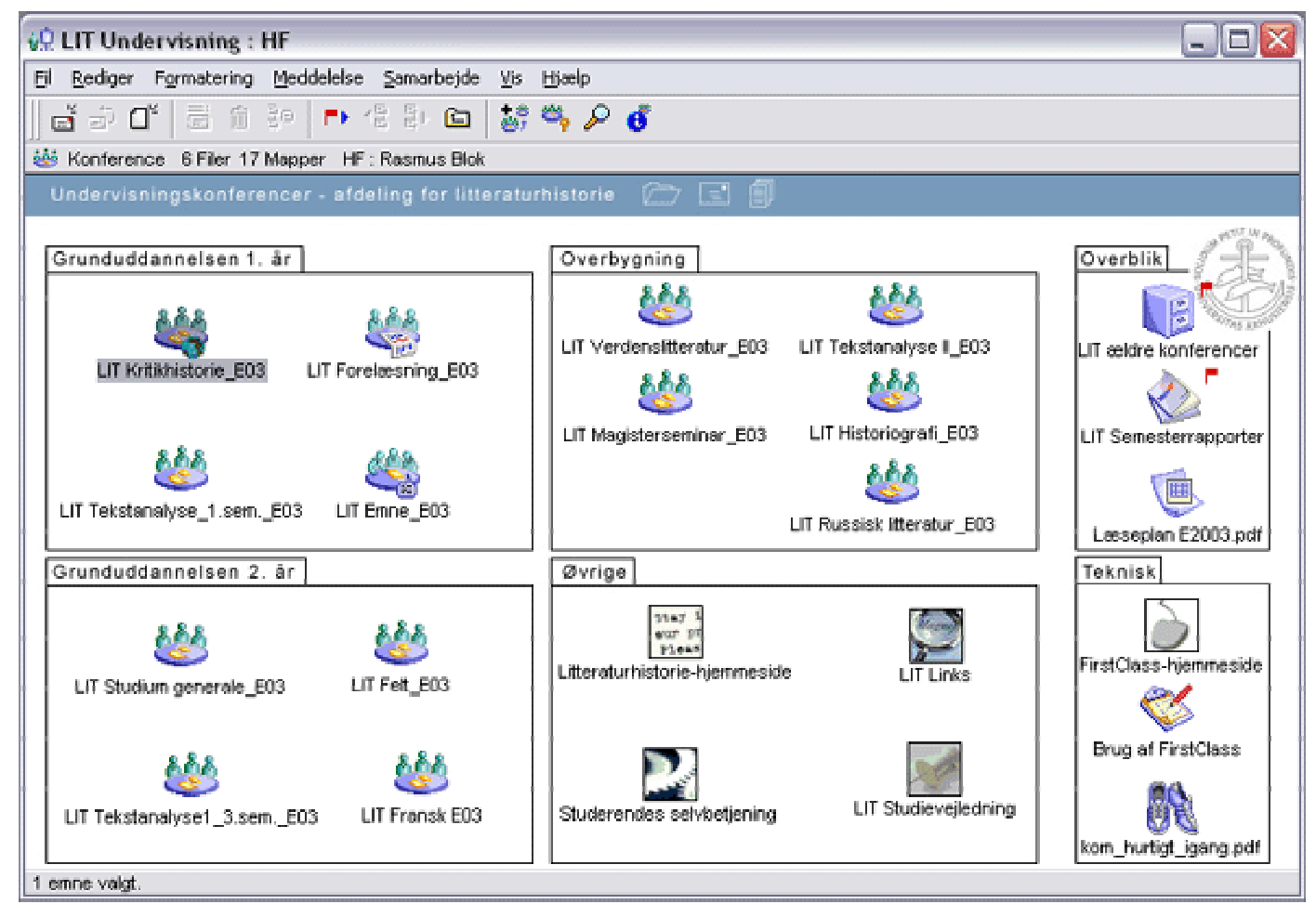

Figur 1. I konferencen LIT Undervisning på Afd. for Litteraturhistorie, Inst. for Astetiske Fag, Aarhus Universitet er alle fagets undervisningsrelaterede konferencer samlet for de studerende. Prcfikset LIT fortceller at konferencerne hører hjemme på Litteraturhistorie.

Diskussionerne i de åbne fora bliver automatisk "trådet", således at respons og svar på de enkelte meddelelser grafisk vises at være relaterede, og giver en indikation af udviklingen. En kollaborativ og samarbejdende tilgang til læring gives hermed grobund, uden at de studerende behøver at være fysisk til stede samtidig, ligesom muligheden for vejledning $\mathrm{mm}$. fra underviseren også gøres fri af fysisk tilstedeværelse. 


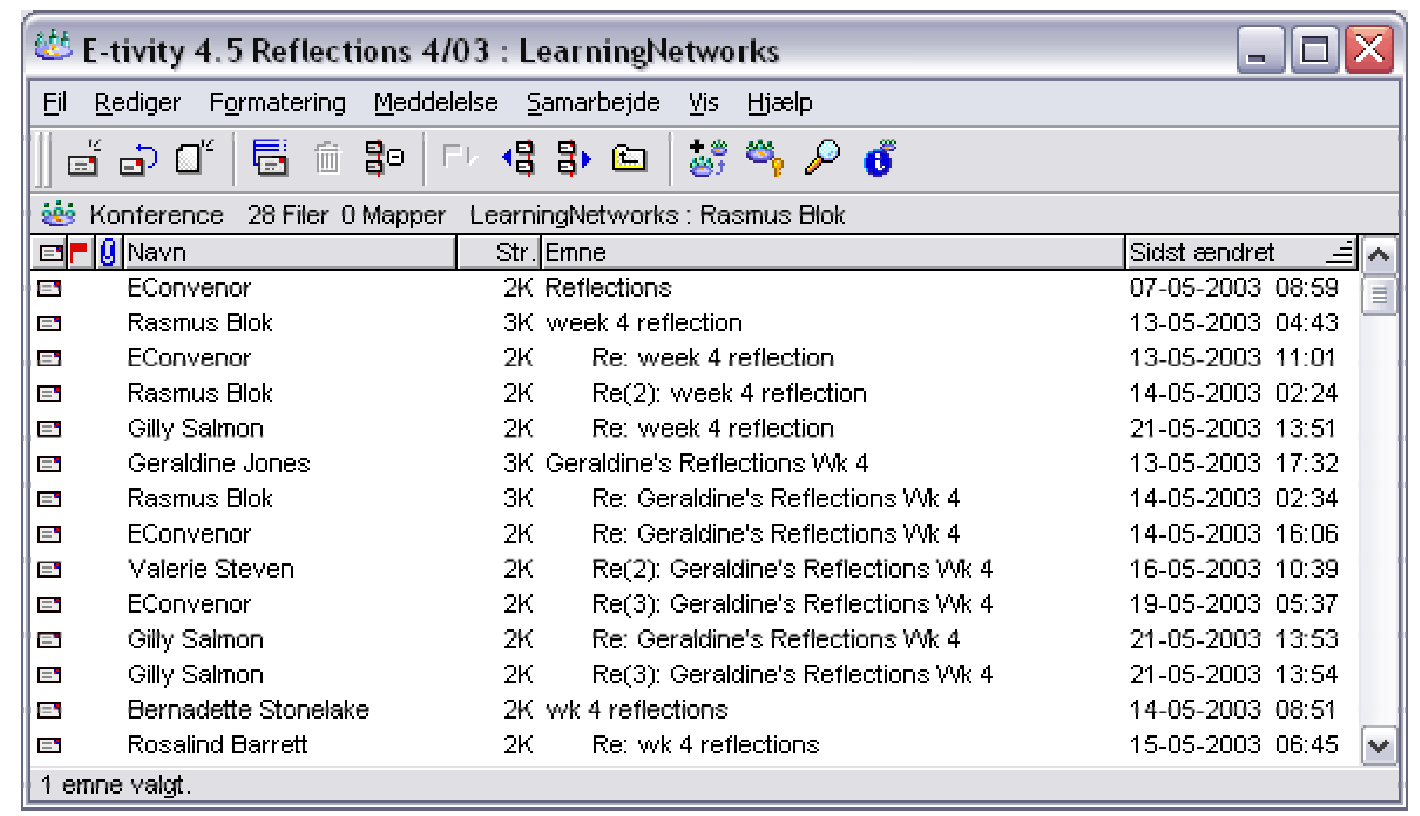

Figur 2. Her ses en trådet diskussion fra et online kursus hos LearningNetworks. Laeg morke til hvordan FirstClass grupperer og tråder diskussionerne, så de fremstår samlet og let overskuelige.

De computermedierede konferencer giver ikke kun blot mulighed for at skabe fora til brug for diskussion, eller forskellige fora for diverse diskussionsemner, men åbner også muligheden for at benytte disse fora som containere af bestemt information. Gennem disse fora, er det muligt at opbygge et overskueligt virtuelt læringsmiljø, hvor løbende eller stationær information kan stakkes og bundtes i tilrettede kasser (konferencer). Læseplaner, ændringer, diskussioner mm. kan samles i en konference, faglig diskussion af et bestemt emne $i$ en anden, spørgsmål og besvarelse vedr. brug af konferencesoftwaren mm. i en tredje, samarbejde $i$ grupper i en række andre, løs snak i en femte osv. alt afhængig af hvordan det virtuelle læringsrum skal struktureres og indrettes i forhold til e-læringens formål og emne.

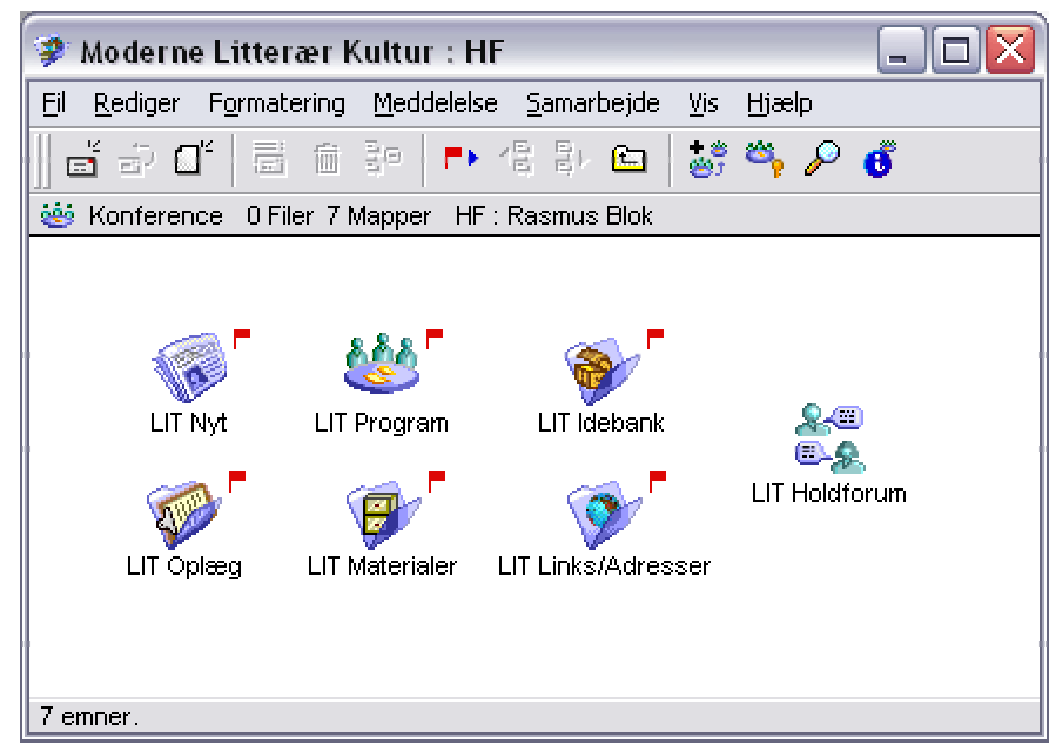

Figur 3. Her ses en enkelt holdkonference, hvis opdeling afspejler forløbets karakter og basering på idéopbygning og oploeg. Her forløbet Moderne Littercer Kultur, som jeg kørte som et delvist online e-laeringsforløb på Afd. for Litteraturhistorie. 


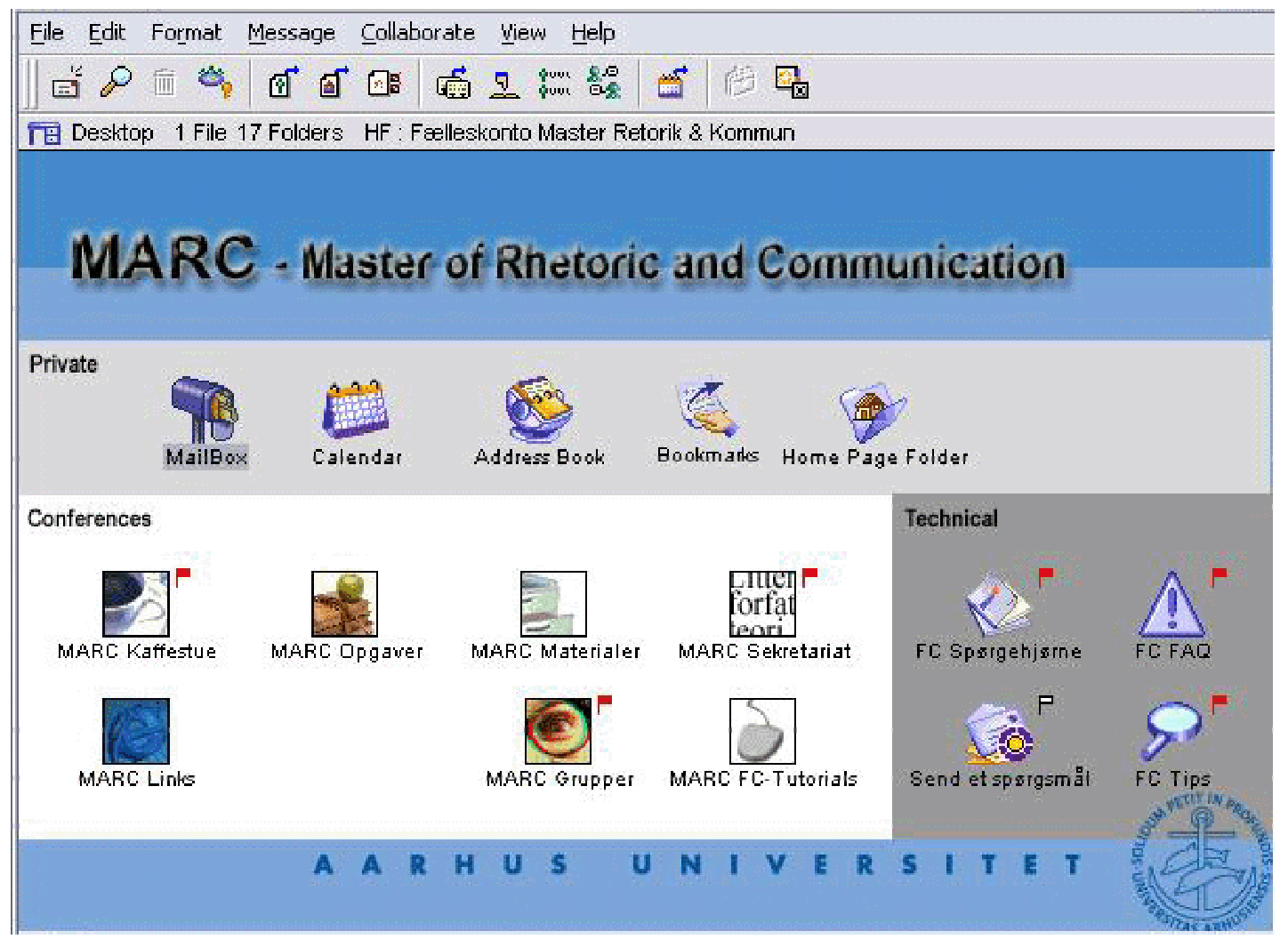

Figur 4. Her en konference for en hel uddannelse, som delvist kører online via FirstClass. Interfacet er set gennem den studerendes egen FirstClass-konto, og indeholder derfor også privat mailbox, kalender, adressebog $\mathrm{mm}$. De røde flag markerer, at der er nye ulceste meddelelser.

Konferencerne og det strukturerede læringsmiljø kan som hovedregel gøres til genstand for rettigheder og begrænsninger i brugen. Konferencen kan gives en række særlige karakteristi$\mathrm{ka}$, eller de enkelte studerende eller grupper af dem kan gives forskellige differentierede rettigheder til den. I FirstClass kan man minutiøst bestemme hvem der skal have lov til hvad i konferencen. Rettighederne kan selvfølgelig variere fra konference til konference og alt afhængig af konferencens mål og den valgte pædagogik i e-læringen. Man vil måske kun arbejde med en ordstyrer-funktion i nogle sammenhænge og ikke i andre. Nogle gange skal alle have lov til at kunne oprette dokumenter og meddelelser i konferencen, mens det i andre måske kun er underviseren, der skal have den rettighed. Man kan også forestille sig situationer hvor man vil invitere andre studerende eller evt. blot det andet hold ind i en konference, men kun vil give dem lov til at læse og intet andet. I grupperummene kan man også forestille sig at de studerende er interesseret $i$ at underviseren ikke kan følge for meget med i hvad der foregår, da det er en proces i sin vorden. Der er således uanede muligheder for at strukturere sine konferencer, så de kan tilgodese stort set alle de arbejdsrelationer de ønskes at indgå i. På lignende vis findes der også ofte rettigheder til de private og offentlige kalendere man kan oprette i konferencesystemerne, så der ligeledes kan sættes skik på brugen af dem. 


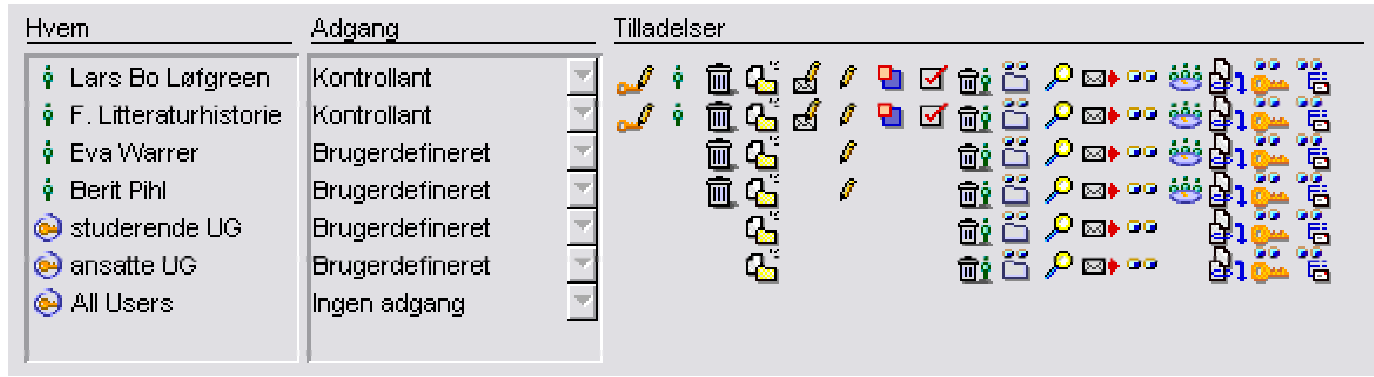

Figur 5. Her ses varieteten af brugerrettighederne for en konference på Afd. for Litteraturhistorie. Hvert ikon på listen indikerer en bestemt tilladelse. De to øverste personer er edbmedarbejdere med fulde beføjelser, mens de to noeste er sekretcererne, med udvidede beføjelser. Derefter mere begronsede tilladelser til ansatte og studerende.

\section{Et kommunikationskarakteristisk skift}

Karakteren af den kommunikation, som finder sted i e-læringen via $C M C$ er mærkbart anderledes end den kommunikation vi kender fra den ordinære undervisning ansigt til ansigt i undervisningslokalet. Det skyldes ikke mindst at der sker et skift i medium, fra den oralt medierede undervisning til den computermedierede undervisning. Nedenfor har jeg opridset en række af de mest markante forskelle mellem ordinær undervisning og e-læring, når der fokuseres på kommunikationen:

\begin{tabular}{|c|c|c|}
\hline & $\begin{array}{l}\text { Ansigt til ansigt / ordinær undervis- } \\
\text { ning }\end{array}$ & $\begin{array}{l}\text { Computermedierede konferencer / e- } \\
\text { læring }\end{array}$ \\
\hline $\begin{array}{l}\text { Kommunikations- } \\
\text { kanaler }\end{array}$ & $\begin{array}{l}\text { - I den ordinære undervisning benyttes en } \\
\text { stor varietet af kanaler til kommunikati- } \\
\text { on: ord, intonation, fagter, kropssprog } \\
\text { mm. Selvom ordene synes de primære, så } \\
\text { viser undersøgelser at omkring } 75 \% \text { af } \\
\text { vores kommunikation foregår nonverbalt. }\end{array}$ & $\begin{array}{l}\text { - E-læringen benytter kun en enkelt } \\
\text { kommunikationskanal, som er den tek- } \\
\text { stuelle. Heri ligger for nogen årsagen til } \\
\text { den mere teoretiske pointe, at } C M C \text { kan } \\
\text { opfattes som upersonlig og kold. }\end{array}$ \\
\hline $\begin{array}{l}\text { Kommunikations- } \\
\text { former }\end{array}$ & $\begin{array}{l}\text { - Kommunikationsformen i undervisnin- } \\
\text { gen ansigt til ansigt er synkron - dvs. at } \\
\text { alle er samlet på samme sted på et be- } \\
\text { stemt tidspunkt. } \\
\text { - Kommunikationen er hovedsagligt } \\
\text { verbal, men med mange nonverbale for- } \\
\text { mer iblandet. } \\
\text { - Bidragene i kommunikationen er sjæl- } \\
\text { dent planlagte, men i højere grad sponta- } \\
\text { ne og improviserede i forhold til den } \\
\text { umiddelbare diskussion. }\end{array}$ & $\begin{array}{l}\text { - Kommunikationsformen i e-læringen er } \\
\text { asynkron - dvs. at den er uafhængig af } \\
\text { fælles tid og sted, men fastsattes af den } \\
\text { enkelte studerende. } \\
\text { - Kommunikationsformen er skriftlig, } \\
\text { men med et verbalt snit. Det er en form } \\
\text { for skriftlig tale, som nogle har betegnet } \\
\text { netspeak (internettale). } \\
\text { - Bidragene i CMC kan ligeledes være } \\
\text { spontane, med masser af slåfejl og } \\
\text { grammatiske fejl, der accepteres på lig- } \\
\text { nende vis, som når vi taler. Omvendt kan } \\
\text { bidragene også være i tråd med de karak- } \\
\text { teristika vi forbinder med almindelig } \\
\text { skrevne tekster: en mere formel og gen- } \\
\text { nemtænkt stil, med korrekt grammatik, } \\
\text { sprogbrug og stavning. } \\
\text { - Bidragene er derfor generelt mere gen- } \\
\text { nemtænkte, og mindre spontane, da der er } \\
\text { bedre tid til at overveje dem, og det tager } \\
\text { længere tid at formulere dem på skrift } \\
\text { end at udsige dem. }\end{array}$ \\
\hline
\end{tabular}




\begin{tabular}{|c|c|c|}
\hline $\begin{array}{l}\text { Kommunikations- } \\
\text { perception }\end{array}$ & $\begin{array}{l}\text { - Kommunikationen er oral og opfattes } \\
\text { som lyd gennem øret. Det stiller krav til } \\
\text { den studerendes koncentrationsevne, idet } \\
\text { kommunikationen kun kan perciperes på } \\
\text { det tidspunkt den udtales. Der er ikke } \\
\text { mulighed for at holde pause eller vende } \\
\text { tilbage for at genoptage kommunikatio- } \\
\text { nen. Ligeledes stiller det krav til et for- } \\
\text { holdsvist roligt miljø, for at kommunika- } \\
\text { tionen kan overføres succesrigt. For me- } \\
\text { get støj og uro vil forstyrre perceptionen } \\
\text { af den mundtlige kommunikation. }\end{array}$ & $\begin{array}{l}\text { - Kommunikationen er skriftlig og afko- } \\
\text { des gennem læsning via synssansen. Det } \\
\text { stiller krav til læsefærdighederne hos de } \\
\text { studerende, men kommunikationen kan } \\
\text { gås til og fra som koncentrationsevnen } \\
\text { går op og ned. Perceptionen af den skrift- } \\
\text { lige kommunikation forstyrres ikke på } \\
\text { samme måde af uro, støj eller andre ude- } \\
\text { frakommende elementer. }\end{array}$ \\
\hline $\begin{array}{l}\text { Kommunikations- } \\
\text { skift }\end{array}$ & $\begin{array}{l}\text { - I den ordinære synkrone undervisning } \\
\text { må man skiftes til at snakke og bidrage til } \\
\text { kommunikationen. Man må stille sig i kø } \\
\text { og vente på ens tur til at snakke. Ofte kan } \\
\text { man i den forbindelse opleve, at diskus- } \\
\text { sionen er drejet væk fra det man vil bi- } \\
\text { drage om, når det bliver ens tur. } \\
\text { - Som regel er der umiddelbar feedback } \\
\text { på alle bidrag og indlæg i diskussionen. }\end{array}$ & $\begin{array}{l}\text { - I e-læringens asynkrone kommunikation } \\
\text { via } C M C \text { er der ikke behov for at vente } \\
\text { på ens tur - her kan man altid bidrage når } \\
\text { man har lyst, enten som en spontan hand- } \\
\text { ling eller som et velgennemtænkt bidrag. } \\
\text { Man har således mulighed for at kom- } \\
\text { mentere og forholde sig til alle bidrag, og } \\
\text { behøver derfor ikke kun at holde sig til } \\
\text { det seneste aktuelle bidrag. } \\
\text { - Responsen er sjældent umiddelbar, men } \\
\text { forekommer oftest med en mindre forsin- } \\
\text { kelse. }\end{array}$ \\
\hline $\begin{array}{l}\text { Kommunikations- } \\
\text { fremtrædelse }\end{array}$ & $\begin{array}{l}\text { - Bidragene i diskussionen ansigt til an- } \\
\text { sigt er mundtlige og fremtræder derfor } \\
\text { som flygtige og med en kort leve- og } \\
\text { hukommelsestid. De er svære at gøre til } \\
\text { genstand for analyse og refleksion, da de } \\
\text { ikke har en permanent fremtræden. }\end{array}$ & $\begin{array}{l}\text { - Bidragene til diskussionen via } C M C \text { har } \\
\text { på baggrund af deres skriftlighed en } \\
\text { permanent fremtrædelse. Alle kan se dem } \\
\text { og alle kan vende tilbage til dem, for } \\
\text { endnu en gennemlæsning. Det danner } \\
\text { mulighed og grobund for analyse og } \\
\text { refleksion. }\end{array}$ \\
\hline $\begin{array}{l}\text { Kommunikations- } \\
\text { socialisering }\end{array}$ & $\begin{array}{l}\text { - De studerende i den ordinære undervis- } \\
\text { ning er i diskussionerne underlagt en } \\
\text { socialiseringsproces, som på forskellig } \\
\text { vis hierarkiserer undervisningsmiljøet. } \\
\text { Dvs. aspekter som race, udseende, være- } \\
\text { måde, fremtoning, status mm. kan få } \\
\text { indflydelse på diskussionen. }\end{array}$ & $\begin{array}{l}\text { - De studerende er med e-læring afskåret } \\
\text { for at se hinanden, og aspekter af race, } \\
\text { udseende, fremtoning, status og væremå- } \\
\text { de får derfor mindre betydning i sociali- } \\
\text { seringen og øger derfor mindre indflydel- } \\
\text { se på diskussionerne. Der sker på den } \\
\text { baggrund en udfladning af den sociale } \\
\text { hierarkisering, der skaber mere ensartede } \\
\text { forhold for diskussion. }\end{array}$ \\
\hline $\begin{array}{l}\text { Kommunikations- } \\
\text { vedligeholdelse }\end{array}$ & $\begin{array}{l}\text { - Eftersom den mundtlige kommunikati- } \\
\text { on i klasseværelset sjældent præserveres, } \\
\text { men blot forsvinder ud i luften, kræver } \\
\text { den ikke nogen nævneværdi vedligehol- } \\
\text { delse. Fra tid til anden vil der opstå situa- } \\
\text { tioner i den mundtlige kommunikation, } \\
\text { hvor man vil prøve at genskabe eller } \\
\text { erindre tidligere diskussioner, men sjæl- } \\
\text { dent ud fra et ønske om en ordret gengi- } \\
\text { velse. Der synes at være en accept af at } \\
\text { kommunikationen med tiden forsvinder } \\
\text { og glider ud af erindringen. }\end{array}$ & $\begin{array}{l}\text { - Den skriftlige kommunikation eksisterer } \\
\text { som regel i konferencesystemet og ved- } \\
\text { bliver med at eksistere dér indtil den evt. } \\
\text { slettes. Dermed præserveres den skriftli- } \\
\text { ge kommunikation og det medfører en } \\
\text { række forhold, som er ukendt fra den } \\
\text { mundtlige kommunikation. Fx vil kom- } \\
\text { munikationen hurtigt hobe sig op og gøre } \\
\text { et overblik umuligt, og der opstår da et } \\
\text { behov for at 'rydde op', dvs. sortere } \\
\text { meddelelserne og fjerne gamle meddelel- } \\
\text { ser. Det kan ske enten ved at slette de } \\
\text { gamle meddelelser, eller ved at oprette } \\
\text { arkiver og flytte dem derover, så de sta- } \\
\text { dig er tilgængelige. Hertil også afrundin- } \\
\text { ger og opsamlinger af diskussioner. }\end{array}$ \\
\hline
\end{tabular}

Skema 1. 
På baggrund af denne lille karakteristik af forskelle er det ikke mærkeligt, at man gennem elæring ofte oplever en nedbrydning af en lang række af de kommunikationsbarrierer, som man sædvanligvis er vidne til i den ordinære undervisning ansigt til ansigt. Netop i sin relative mangel på social hierarkisering og mere ensartet base for kommunikation og samarbejde, er elæringen bl.a. med til at bringe størstedelen af de studerende, der i den ordinære undervisning af forskellige grunde udviser modvillighed mod aktiv deltagelse i diskussionerne og undervisningsarbejdet, ind i en mere aktiv og deltagende rolle. Den store ensartethed og forudsætningslighed for kommunikationen i e-læringen er befordrende for diskussionen og tilvejebringer alle med lige indgang og mulighed til den. Det ses også af, at dem som kan have tendens til at virke styrende i diskussioner ansigt til ansigt, sjældent er det i de online konferencer.

Mens e-læring kan være med til at nedbryde barrierer for kommunikationen, kan dens mangel på fysisk og synlig gestik mm. samtidig være årsag til dannelsen af en række andre forhindringer for kommunikationen, hvis man ikke er påpasselig. Det, ikke længere at stå ansigt til ansigt med den person man diskuterer med, foranlediger nogle til at være mere kritiske end nødvendigt eller fremture mere aggressivt. Det kan være med til at skabe et dårligt diskussionsklima, hvor opmærksomheden flyttes væk fra det faglige emne for diskussionen til et mere regulært skænderi mellem en eller flere personer. Sådanne konflikter opstår som regel fordi man glemmer en af de vigtigste præmisser for kommunikationen online, at der gælder samme menneskelige regler for kommunikationen online som ansigt til ansigt. Man skal således ikke skrive noget, som man ikke helt sikkert kunne sige hvis personen stod lige foran en.

Manglen på synlig gestik og intonation og ofte også manglen på erfaring med online kommunikation kan ligeledes medføre regulære misforståelser, de diskuterende og kommunikerende parter imellem. Ofte sker misforståelserne helt uforvarende for både afsender og modtager, idet de begge mener at have skrevet og læst kommunikationen "lige ud af landevejen". Manglen på udenomsskriftlige hints gør at andre faktorer får større betydning for kodningen og afkodningen af kommunikationen. Det kan være kulturelle, sociale og faglige forhold der kan spilde ind, og være genstand for misforståelse. Ikke mindst gælder det når humor og ironi er indblandet. Det er således ikke usædvanligt, at morsomheder eller ironiske bemærkninger, let læses for at være sarkasme eller upassende kritiske bemærkninger. Man bør derfor være varsom med humor og ironi i online kommunikation, men omvendt heller ikke tilsidesætte den helt, da den (særligt i en skandinavisk tradition) kan være med til at socialisere de studerende og dermed gavne det kommunikative miljø.

Et vigtigt element $\mathrm{i}$ arbejdet med e-læring er således at skabe enighed om vilkår for kommunikationen online. Generelt bør de studerende være bekendt med grundlæggende regler for netikette (online etikette) og god kommunikativ opførsel. Sammen med fælles vedtagne retningslinjer, der sætter rammerne for hvad der er acceptabelt og hvad der ikke er, kan langt de fleste misforståelser og uønskede situationer undgås. Endvidere kan man også henlede de studerendes opmærksomhed på benyttelsen af emoticons (ikoner for følelser), der kan være et godt supplement til at gøre sig forståelig online, og dermed undgå misforståelser og irritation. Brugen af emoticons er efterhånden meget udbredt, og selvom de både er elsket og hadet, så afspejler de måske vigtigst af alt, at den online kommunikation er under udvikling og væsensforskellig fra den synkrone kommunikation ansigt til ansigt.

\section{Konferencers varierede formål i e-læringen}

Alt afhængig af fagligt emne og formål, kan der være mange forskellige pædagogiske, praktiske og kulturelle mål, som stiller krav til udformningen og brugen af $C M C$ i e-læringen. Hvad man skal opnå gennem e-læringen og hvilke faglige og pædagogiske redskaber man vil benytte i tilknytning til de online konferencer varierer selvfølgelig meget, og vil sætte sit præg på 
udformningen af det virtuelle læringsrum. Omvendt sætter $C M C$ som e-læringsteknologi, og dertil pædagogiske implikationer, også en række betingelser for hvad der er muligt og hvad der er fordelagtigt. Nedenfor har jeg listet en række eksempler på forskellige kategorier af formål og brug af konferencer i e-læringen, som jeg har fundet nyttige og som måske kan være til inspiration. Der vil sikkert være mange flere, ligesom en række af dem i nogle sammenhænge med fordel vil kunne kobles sammen, og andre adskilles yderligere.

\begin{tabular}{|c|c|}
\hline Kategori & Formål og brug \\
\hline $\begin{array}{l}\text { Opslagstavle, vigtige } \\
\text { meddelelser mv. }\end{array}$ & $\begin{array}{l}\text { - Et fast forum hvor meddelelser om ændringer, aflysninger, nye tidspunkter og } \\
\text { andet nyt vedr. forløbet, faget, kurset og lignende er uundværligt for ethvert e- } \\
\text { læringsforløb. Det er vigtigt at få etableret et klart markeret sted for den type } \\
\text { meddelelser, så de studerende altid ved hvor de skal finde dem og holde sig } \\
\text { orienteret. Hvis sådanne informationer spredes forskellige steder eller kun for- } \\
\text { ligger en gang imellem, så mister den studerende motivationen til selv at holde } \\
\text { øje, ligesom der er stor fare for at meddelelserne ikke når frem. } \\
\text { - Lav gerne regler for hvornår og hvordan meddelelser bringes og læses af un- } \\
\text { derviser og studerende, og sørg for at andre typer meddelelser ikke iblandes } \\
\text { disse. }\end{array}$ \\
\hline Program, tidsplan mv. & $\begin{array}{l}\text { - Blandt uundværlige fora er også et rum for undervisningens program, tidspla- } \\
\text { ner mm., som de studerende kan holde sig til. Særligt når det gælder e-læring er } \\
\text { der et stort behov for at få program- og skemalagt undervisningen, idet under- } \\
\text { visningen jo er tids- og stedsfleksibel. De studerende har derfor stort behov for } \\
\text { at vide hvor og hvornår de forventes at deltage og begynde eller afslutte under- } \\
\text { visningselementer. } \\
\text { - Hvor man i undervisningen ansigt til ansigt altid kan spørge en fra holdet, der } \\
\text { ved eller kan huske hvad man skal næste gang eller lignende, så har man som } \\
\text { studerende via e-læring ikke de samme muligheder. Det stiller krav om større } \\
\text { synlighed af program, tidsplan mv. }\end{array}$ \\
\hline $\begin{array}{l}\text { Studenterforum, kaf- } \\
\text { febar \& studenterca- } \\
\text { fé, chatforum) }\end{array}$ & $\begin{array}{l}\text { - Endnu et svært uundværligt, men ofte overset, fora er den virtuelle kaffebar, } \\
\text { kantine, studenterforum eller lignende rum for løs snak og meddelelser de stude- } \\
\text { rende imellem. Ligesom kantinen, gangen eller caféen giver de studerende mu- } \\
\text { lighed for at udveksle erfaringer, løs snak og uforpligtende ord om faglige og } \\
\text { ikke-faglige emner, så har e-læringsstuderende også brug for et sådant frirum. } \\
\text { Ofte er behovet større, da et sådant forum udgør en stor og afgørende bestanddel } \\
\text { i de studerendes socialisering med hinanden. } \\
\text { - Desuden er det ofte sådan at den løse snak som foregår i kantinen eller i den } \\
\text { virtuelle kaffebar er meget frugtbar for det faglige perspektiv i undervisningen. } \\
\text { På den ene side kan et sådant forum være med til at skille skidt for sig og snot } \\
\text { for sig, så de faglige og undervisningsrelaterede diskussioner ikke infiltreres af } \\
\text { den løse snak. Men også fordi meget af den løse snak og uforpligtende faglige } \\
\text { udveksling ofte fører faglige initiativer med sig af stor vigtighed. Hvem kender } \\
\text { ikke til faglige tiltag, som er fremkommet over en kop kaffe i kantinen? }\end{array}$ \\
\hline $\begin{array}{l}\text { FAQ (Frequently } \\
\text { Asked Questions - } \\
\text { da. ofte stillede } \\
\text { spørgsmål) }\end{array}$ & $\begin{array}{l}\text { - I e-læringen vil der ofte vise sig at være en række spørgsmål (særligt om tekni- } \\
\text { ske aspekter), som stilles igen og igen, og som har almen karakter. Frem for at } \\
\text { skulle besvare spørgsmålene igen og igen, eller henvise spørgsmålene et bestemt } \\
\text { sted hen (fx til en IT support-afdeling), kan det være en stor fordel at udarbejde } \\
\text { en liste over de mest gængse spørgsmål - en såkaldt FAQ. Med en sådan kan } \\
\text { man opfordre de studerende til at besøge } F A Q ' e n \text { først, før de spørger løs, og } \\
\text { dermed spare tid og kræfter for både studerende, underviser og evt. supporter. } \\
F A Q ' e n \text { har tillige den fordel, at den kan genbruges i alle lignende sammenhæn- } \\
\text { ge, og kun kræver energi at oprette første gang og senere måske blot moderere } \\
\text { eller justere. Der er selvfølgelig intet til hinder for at man kan have flere } F A Q ’ e r \\
\text { om forskellige emner. } \\
\text { - Udarbejdelsen af en fagspecifik } F A Q \text {, kan samtidigt være et ret godt fagligt og } \\
\text { pædagogiske stykke arbejde i undervisningssammenhæng, og som kan give } \\
\text { anledning til spændende faglige diskussioner. }\end{array}$ \\
\hline
\end{tabular}




\begin{tabular}{|c|c|}
\hline $\begin{array}{l}\varnothing v e l s e s k o n f e r e n c e r, \\
\text { e-tiviteter }\end{array}$ & $\begin{array}{l}\text { - E-læringen indebærer jo selvfølgelig en række øvelser foruden rækken af støt- } \\
\text { tende konferencer og fora. Disse kan have meget forskellig karakter, omfang og } \\
\text { rækkevidde, og kan fx være centreret om et bestemt emne, struktureret over en } \\
\text { læseplan eller noget helt tredje. Øvelserne kan alle være givet på forhånd, eller } \\
\text { de kan komme til hen ad vejen, alt afhængig af valgt pædagogik og sigte. Forde- } \\
\text { len ved at have alle øvelserne givet på forhånd, er at det giver overskuelighed og } \\
\text { gennemsigtighed for de studerende, mens øvelser hen ad vejen kan forekomme } \\
\text { rodet og uden rød tråd. Omvendt kan de helt planlagte forløb også opfattes lidt } \\
\text { for rigidt og ikke levne plads til nyt og aktuelt stof, som en planlægning hen ad } \\
\text { vejen kan åbne op for. Særlige konferencer for øvelser er under alle omstændig- } \\
\text { heder en god idé og gerne med klare angivelser af hvad der forventes af de stu- } \\
\text { derende - hvor, hvornår og hvordan. }\end{array}$ \\
\hline $\begin{array}{l}\text { Ressourcer og } \\
\text { materialer }\end{array}$ & $\begin{array}{l}\text { - Det vil ofte være en god idé at oprette en fast mappe eller konference, hvori alt } \\
\text { materiale til brug for undervisningen, samt evt. ekstra ressourcer forefindes. Det } \\
\text { vil lette den studerende arbejde og give dem sikkerhed for at de altid kan finde } \\
\text { materialet - også efter at det er blevet benyttet i undervisningen, fx i forbindelse } \\
\text { med en eksamenssituation. Man kan evt. inddele konferencen med underkonfe- } \\
\text { rencer for hver uge eller emne, alt afhængig af undervisningens sammensæt- } \\
\text { ning. } \\
\text { - For at undgå rod eller forvirring om ressourcerne og materialerne, kan det } \\
\text { under visse situationer være en god idé at låse konferencen, således det kun er } \\
\text { underviseren der kan lægge materialer ind i konferencen, eller man kan gøre } \\
\text { underviseren til 'ordstyrer' af konferencen, således at materiale der lægges ind, } \\
\text { skal godkendes af denne. }\end{array}$ \\
\hline Links & $\begin{array}{l}\text { - Ressourcer på Internettet bliver en større og større del af det pensum som un- } \\
\text { dervisningen generelt bygger på, og er selvfølgelig oplagt at benytte i e- } \\
\text { læringen, da man i forvejen er forbundet til Internettet. Links til gode og nyttige } \\
\text { hjemmesider udgør derfor et vigtigt bidrag til læringen og vidensopbygningen. } \\
\text { Men med Internettets hastige udvikling og enorme omfang kan det være svært at } \\
\text { kende alle gode og relevante links. Udveksling af links er derfor blevet en ind- } \\
\text { bygget logik i omgangen med Internettet og særdeles nyttig ud fra et lærings- og } \\
\text { undervisningsmæssigt synspunkt. Det er derfor altid nyttigt at oprette en konfe- } \\
\text { rence eller forum hvor links kan lægges ind, samt udveksles frit de studerende } \\
\text { imellem. Man kan evt. oprette forskellige kategorier for linkene, så der kan } \\
\text { skelnes mellem faglige kategorier og evt. mellem officielle og uofficielle links. } \\
\text { Sørg for at lave en praksis, hvor linkene bliver ordentligt beskrevet og navngi- } \\
\text { vet, så de er let at skelne imellem. }\end{array}$ \\
\hline Grupperum & $\begin{array}{l}\text { - Ofte vil en del af e-læringen fordre arbejde i grupper, eller på anden led kræve } \\
\text { samarbejde de studerende imellem, hvor de er opdelt. Hertil er det ofte nødven- } \\
\text { digt at tilvejebringe de studerende med nogle rammer, hvor den enkelte gruppe } \\
\text { kan boltre sig uforstyrret og omvendt heller ikke være til gene for de øvrige } \\
\text { grupper og studerende. Særlige konferencer til gruppearbejde er derfor nødven- } \\
\text { dige, hvor de studerende kan diskutere mv. for 'lukkede døre'. Evt. kan de stu- } \\
\text { derende i gruppen indrette sig med underkonferencer og mapper til fælles mate- } \\
\text { rialer, links, udkast, referater mv., som kun har interesse internt i gruppen. } \\
\text { Grupperummene kan gøres provisoriske og evt. åbne, eller permanente og evt. } \\
\text { lukkede, alt afhængig af undervisningsmæssig karakter og formål. }\end{array}$ \\
\hline Debatforum & $\begin{array}{l}\text { - Styrken ved e-læring er bl.a. de gode betingelser for diskussion og debat. Ofte } \\
\text { vil debatten og diskussionen være en integreret del af undervisningen og dens } \\
\text { øvelser. Men man kan også godt forestille sig at nogle diskussioner har et mere } \\
\text { langsigtet perspektiv, hvor det vil være frugtbart at diskutere over længere tid, } \\
\text { eller vedblive at diskutere i lyset af ny viden fra undervisningen. Det kan også } \\
\text { være at de studerende af egen drift finder emner, måske udsprunget af øvelser } \\
\text { og undervisning, som de ønsker at holde en diskussion i gang om. Til sådanne } \\
\text { formål, kan man benytte } C M C \text { til at oprette en eller flere konferencer, som et } \\
\text { slags debatforum. Man kan have flere samtidigt, opdelt efter emne, ligesom de } \\
\text { kan oprettes og nedlægges uafhængigt af den øvrige undervisning og efter lyst } \\
\text { og behov. }\end{array}$ \\
\hline
\end{tabular}




\begin{tabular}{|l|l|}
\hline Kalender & $\begin{array}{l}\text { - Nogle undervisningsforløb, hold eller lignende kan have en undervisning, hvor } \\
\text { der indgår mange aftaler på skiftende tidspunkter, eller på anden vis have behov } \\
\text { for at tydeliggøre undervisningen gennem en kalender. Fx hvis dele af undervis- } \\
\text { ningen foregår ved fysiske møder på vekslende tidspunkter. Kalenderen kan } \\
\text { også benyttes til at vise hvem der er ansvarlig uge for uge for fx oprydning i } \\
\text { konferencer, udarbejdelse af referater, opsamlinger af diskussioner eller andre } \\
\text { funktioner, som de studerende skal klare. } \\
\text { - Brug af kalenderfunktionen kan let blive redundant eller overflødig. En tom- } \\
\text { melfingerregel er derfor, at man kun skal oprette og gøre brug af en sådan, hvis } \\
\text { der foregår noget på ugebasis. Er der mindre begynder der ofte at vise sig et } \\
\text { svigtende engagement til at benytte den. }\end{array}$ \\
\hline $\begin{array}{l}\text { Oplæg, indlæg, refe- } \\
\text { rater, } \\
\text { mm. }\end{array}$ & $\begin{array}{l}\text { - Et sæamlingt forum for referater, studenteroplæg, opsamlinger af diskussioner } \\
\text { mm. kan være nyttigt, så de studerende har mulighed for at fă fat i dem senere i } \\
\text { undervisningsforløbet og gøre brug af dem til andre diskussioner, opgaver eller } \\
\text { eksamen. Tillige kan de, som af forskellige årsager fx ikke har deltaget i en } \\
\text { bestemt diskussion, gennem en opsamling af den få lejlighed til også at drage } \\
\text { nytte af den og bedre følge med videre i undervisningen. }\end{array}$ \\
\hline $\begin{array}{l}\text { Referencer, litteratur- } \\
\text { liste }\end{array}$ & $\begin{array}{l}\text { - I tilfælde at undervisningen kræver meget læsning, eller afkaster en masse } \\
\text { referencer på videre læsning, kan det være en god idé med en litteraturliste eller } \\
\text { forum for referencer, så de er samlet ét sted. Så er det også lettere for den stude- } \\
\text { rende at holde styr på dem, ligesom alle kan få gavn af dem på samme tid. }\end{array}$ \\
\hline
\end{tabular}

Skema 2.

\section{E-læringens ændrede motivations- og deltagelsesforhold}

I relation til den ændrede kommunikationsform og de nye formålskategorier for undervisningens strukturering, er det værd at hæfte sig ved, at der også opstår et ændret mønster for de studerendes deltagelse og motivation. Her spiller en række faktorer ind, som både er teknisk, pædagogisk og socialt betingede. Nedenfor er angivet fire forhold vedr. e-læring via $C M C$, som kan spille ind på den studerendes motivation og mønster for deltagelse:

\section{1: Den studerendes kontekst}

Konteksten for den enkelte studerende eller gruppen af studerende er særlig vigtig og har stor indflydelse på brugen og struktureringen af $C M C$, og et succesrigt udfald. Først og fremmest er det vigtigt at finde ud af hvorfor de studerende deltager i undervisningen. Det er der måske ret ligefremme svar på for studerende i gymnasiet, mens det fx kan se ret anderledes ud for en masteruddannelse på universitetet. For nogle er det interesse, andre er det et mål om et bestemt job og for helt andre måske et krav fra arbejdspladsen, der angiver hvorfor de deltager. Sammensætningen af de studerende, samt deres baggrund for at deltage er vigtige faktorer for underviseren i udarbejdelsen af pædagogik og læringsstategier for e-læringen. De forskellige årsager giver forskellige motiverende faktorer, som gerne skulle understøttes i undervisningen, for at den studerende kan føle den som vedkommende og givende.

Yderligere har de studerendes faglige baggrund, deres kendskab til og erfaring med IKT og deres adgang til undervisningen også effekt på e-læringen. Ligesom vi indretter vores kommunikation efter hvem vi snakker med, så er det klart at undervisningen også bør tilrettelægges efter om de studerende overvejende er unge gymnasieelever, seminariestuderende med linjefag i fysik, kandidatstuderende i kemi på universitetet eller tidligere kandiderede jurister i gang med en masteruddannelse. Det kan samtidigt også være et fingerpraj om hvordan og hvorledes de studerende tilgår e-læringen. Er det via skolernes computere, via arbejdspladsens arbejdsstation eller sker det i køkkenet, arbejdsværelset eller noget andet hjemme i den private bolig? Sker det om eftermiddagen efter skole, om aftenen efter børnene er lagt i seng eller mellem to møder på arbejdet? Og er de studerende prøvede og erfarne brugere af IT, er de vokset om med brugen eller er den fremmed for dem. Sådanne forhold er vigtige at få kortlagt, da viden om dem kan være med til at bedre undervisningen og i høj grad danne baggrund for at kunne forstå de studerendes eventuelle problemer mv. 
Sjældent viser gruppen af de studerende at være 100\% homogen mht. disse faktorer, men udgør i højere grad en broget flok. Brogede flokke har derfor sværere ved at etablere homogenitet fra starten og det kan skabe usikkerhed hos den enkelte, da der således ikke umiddelbart er en stærk egenforståelse at holde sig til. Det er derfor et godt råd, at arbejde med stor åbenhed og gennemsigtighed overfor de studerende i relation til formål, strategi og forløb, da det kan være med til at fjerne væsentlige usikkerhedsfaktorer. Endelig er det også bedre at starte et niveau for lavt, end et niveau for højt, for dermed at sikre en vis jordbundethed og sikkerhed hos de studerende.

\section{2: E-læringens asynkrone natur}

De computermedierede konferencers asynkrone natur, kan kræve tilvænning for den uøvede studerende. Ofte er det et spørgsmål om at erfare og forstå den asynkrone diskussions natur. Vænnet til diskussionen ansigt til ansigt kan diskussionen online let forekomme kaotisk og svævende, eftersom der svares på forskellige tidspunkter og spørgsmål og svar ikke nødvendigvis følges ad i en logisk tidsmæssig udveksling kendt fra den orale diskussion. Nogle vil måske også i starten blive overvældet af omfanget af diskussionerne, eftersom alle nu kan svare og spørge uafhængigt af tid og uden den kendte rækkefølge kendt fra den ordinære undervisning. Atter andre må måske kæmpe med utålmodigheden af ikke at få svar eller respons med det samme, for slet ikke at tale om måske slet ikke at få svar overhovedet, eftersom de øvrige studerende tilgår diskussionen på forskellige tidspunkter. For nogle giver det et savn af spontanitet, mens andre er særlig glad de bedre vilkår for refleksion og omtanke inden besvarelse. Dvs. at mens nogen umiddelbart motiveres af formen, demotiveres andre fordi de måske stiller forkerte forventninger til den nye kommunikationsform.

\section{3: Den tekstbaserede kommunikation}

Et tredje område, som har indflydelse på den studerendes motivation og adfærd er det forhold, at kommunikationen er skriftlig. Det at kommunikationen udelukkende foregår skriftligt i e-læringen bringer nogle andre faktorer i spil, som man ikke på samme vis kender fra traditionen af mundtlig kommunikation. Særligt stavning, syntaks og formuleringsevner kommer i fokus, og kan virke lidt skræmmende på studerende hvad enten de er gode eller mindre gode til dette. Hvor der i den talte diskussion ofte tolereres en særlig jargon, slang, forkerte formuleringer, rettelser osv., synes den skriftlige form ikke at indgyde samme frihed, og tolkes ofte anderledes når de mødes på skrift. Det skyldes mest af alt, at vores skriftkultur indtil nu har været forbeholdt 'langsomme' bøger og lignende, og ikke har inkluderet en hurtig dialogform, da den først nu er blevet mulig. Vi er således uvant med at 'tale' sammen i en skriftlig form, og heraf kan opstå en usikkerhed for den enkelte studerende. Manglen på gestik og intonation, tillige med den uvante diskussionsform, kan derfor være med til at skabe en frygt blandt nogle studerende for at de ikke gør sig forståelige eller bevirke, at de er overomhyggelige med den skriftlige kommunikation - med meget tidsforbrug som bivirkning.

\section{4: Det skrevne ords permanens}

Endelig kan det forhold, at de skrevne ord har længere levetid end det talte også indvirke på adfærden af de studerende. Mens det talte ord i en diskussion forsvinder ud i den blå luft, og derved er svært at vende tilbage til og referere til, så forholder det sig lige omvendt med det skrevne. Den skrevne diskussion kan man vende tilbage til, læse igen og igen og referere til. Det er på mange måder fordelen ved den skrevne diskussion, men kan også virke lidt skræmmende for uvante studerende. Særligt at andre studerende, inklusiv evt. underviseren kan nærstudere deres indlæg og referere til dem og læse dem igen. Det vil for mange være en motiverende faktor til at skrive gode bidrag, men kan også for enkelte virke demotiverende og gøre dem usikre.

\section{Skema 3.}

Langt de fleste studerende udviser en stor motivation blot ved at arbejde med e-læring. Ikke mindst fordi der deri ligger en række friheder og en række store fordele for den enkelte. Ofte handler mulige problemer og demotivation blot om tilvænning til en ny form for kommunikation og læring, og udgør sjældent en permanent faktor. Hvor e-læring ikke er en kendt form eller er helt nyt, vil det ofte være en god idé at arbejde gennemsigt med grundlaget bag elæringen og være åben for tilvænning og evt. problemer der kan opstå. Det er vigtigt at den studerende ikke føler sig forkert, fordi vedkommen har svært ved at vænne sig til e-læringen eller kan være lidt genert med at komme i gang. Nedenfor har jeg listet en række af de fordele 
og ulemper, som studerende ofte nævner ved mødet med e-læring. De kan være nyttige at kende til og evt. tale åbent om med de studerende.

\begin{tabular}{|c|c|}
\hline Fordele ved e-læring & $\begin{array}{l}\text { - } \quad \text { Er uafhængig af tid og sted } \\
\text { - } \quad \text { Der er intet behov for transport til læringsstedet } \\
\text { - } \text { Alle har lige mulighed for at komme til orde } \\
\text { - } \quad \text { Giver bedre forhold for at følge med i diskussionerne for alle } \\
\text { - } \quad \text { Alle kan se og lære af hver enkelt studerendes spørgsmål og svar } \\
\text { - } \quad \text { Mulighed for at vende tilbage til diskussioner, da de er permanente via } \\
\text { - } \quad \text { Mindiften } \\
\text { - } \quad \text { gget informations og vidensmængde grundet alle kan kommunikere med } \\
\text { - } \text { Lælle }\end{array}$ \\
\hline Ulemper ved e-læring & $\begin{array}{l}\text { - Kommunikationsmæssig er e-læring mindre rig en den orale kommunika- } \\
\text { tion, grundet manglen på fx intonation, gestik mm. } \\
\text { - Giver umiddelbart ikke så gode forhold til studerende med ringe stave- } \\
\text { færdigheder (kan dog også anses som en træning) } \\
\text { - Kommunikationsformen er ikke så gennemsigtig som ansigt til ansigt, da } \\
\text { man ikke umiddelbart kan se hvem man taler til. } \\
\text { - Kommunikationsformen kan virke mere kaotisk og uden fast rytme. } \\
\text { - Misforståelser kan være sværere at rette og det kan tage længere tid. }\end{array}$ \\
\hline
\end{tabular}

Skema 4.

\section{Øvrige funktioner og brug af software til e-læring}

Ved at indføre et konferencesystem til e-læring på uddannelsesinstitutionen får man samtidigt et system, der i sig ofte kan integrere flere af de funktioner, som til dagligt benyttes i relation til det at drive en uddannelsesinstitution. I den samme brugerflade, hvor der til undervisningsbrug gives adgang til div. konferencer, kan der mange gange let oprettes og gives adgang til $\mathrm{fx}$ andre institutionelle konferencer, privat mail, private eller institutionelle kalendere, adressebog, bogmærkesamlinger, direkte webudgivelse, fil-overførsler, chat og meget mere. Som regel er konferencesoftwaren en kombination af alle disse ting. Et konferencesystem kan dermed ikke kun gøres til genstand for e-læringen, men kan gøres til redskab for alle på uddannelsesinstitutionen; undervisere, sekretariatspersonale, studievejledere, studerende og administratorer mv. Og hvis man i forvejen benytter konferencesystemet til e-læring, og dermed til en bestemt form for kommunikation med de studerende, så er det jo oplagt at benytte den til meget af al den anden form for kommunikation, som foregår mellem en uddannelsesinstitution og de studerende, eller deres undervisere. 


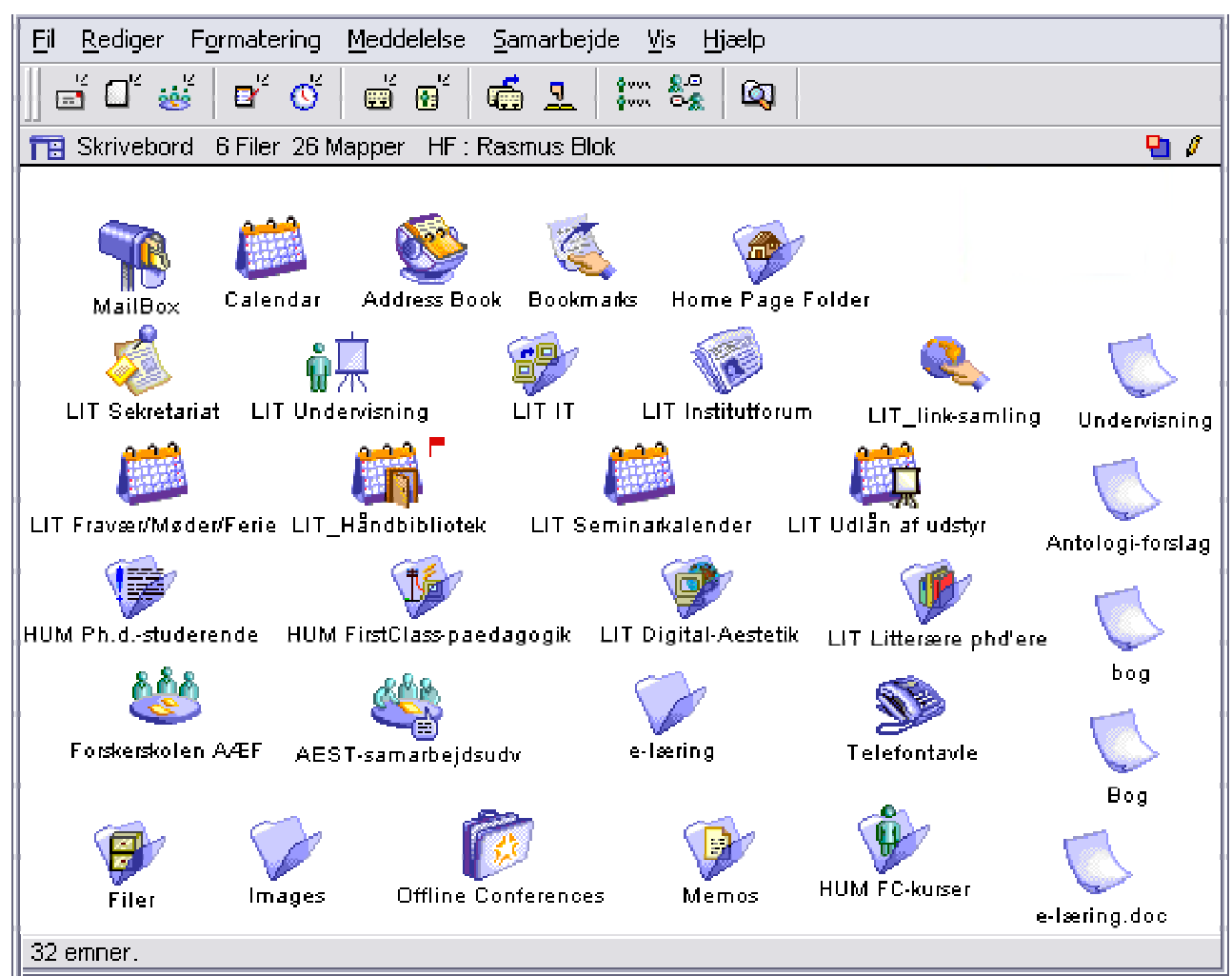

Figur 6. Her min egen desktop i FirstClass på Afd. for Litteraturhistorie, hvor en helt rakke administrative og forskningsrelaterede konferencer også forefindes, iblandt egen privat mailboks, kalender mv. og undervisningskonferencer.

Ved indførelsen af et konferencesystem som et slags intranet (internt netværk) på hele institutionen kan de nævnte funktioner bl.a. være med til at lette kommunikationen i en række former for det institutionelle arbejde, hvad enten det er administration, forskning, teamsamarbejde eller undervisning, ligesom konferencesystemet kan benyttes til at gøre diverse ressourcer tilgængelige i lukkede eller åbne fora og i tværfaglige eller -institutionelle miljøer. I dette arbejde er det som regel også en mulighed at få oprettet enkeltbrugere uden for de tilknyttede institutter. Dette åbner muligheden for at arbejde i et nationalt/internationalt netværk, hvor indlæg kan gøres tilgængelige for de inviterede og omvendt, ligesom rettighederne kan justeres i forhold til den enkelte bruger eller hele grupper. Ligeledes kan elæringssoftwaren benyttes til efteruddannelse og kurser for undervisere og ansatte. 


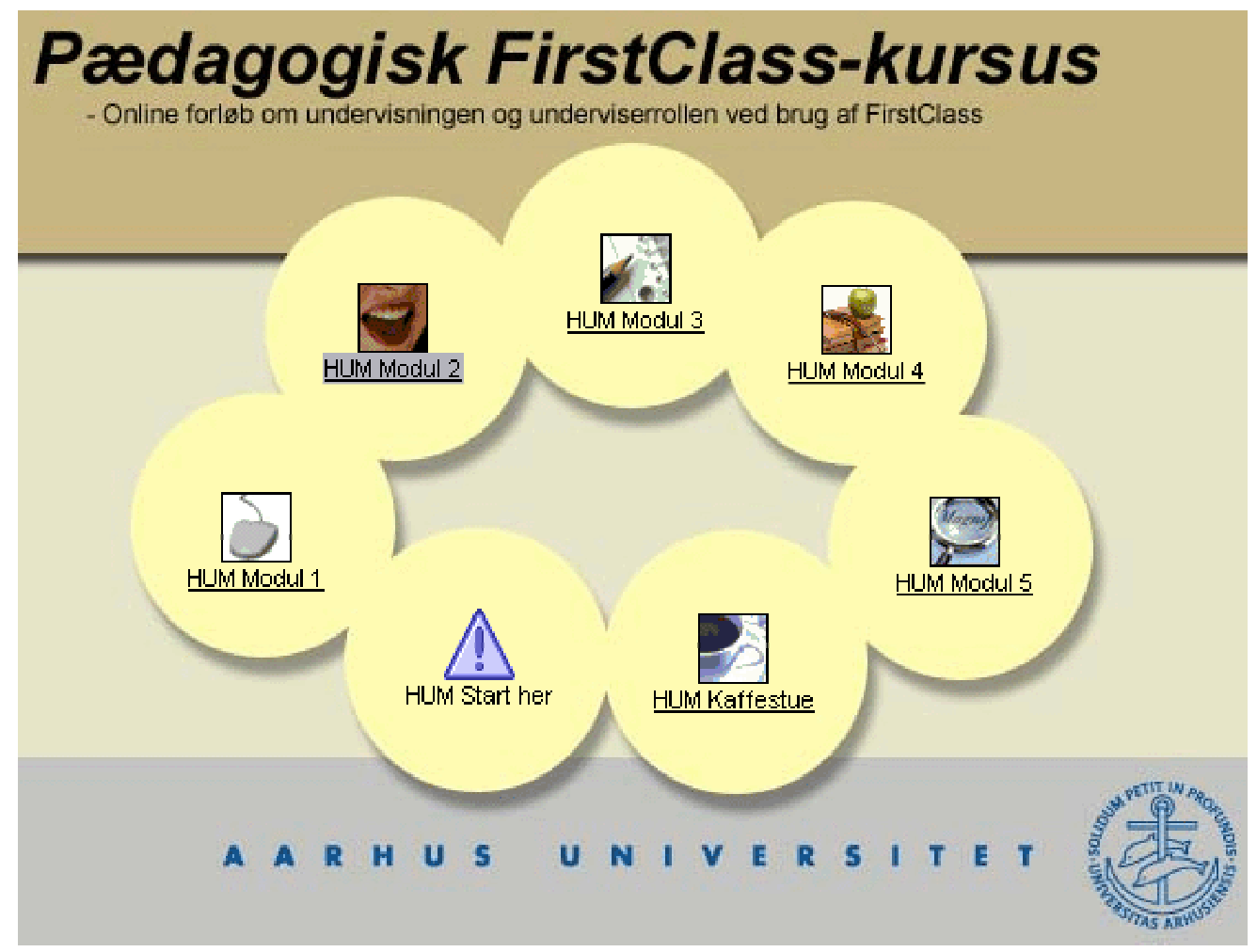

Figur 7. Her ses et eksempel på et efteruddannelseskursus for undervisere netop om brug af FirstClass $i$ undervisningen. Kurset er eksemplarisk $i$ den forstand at det kun foregår $i$ FirstClass som et rent e-loeringsforløb.

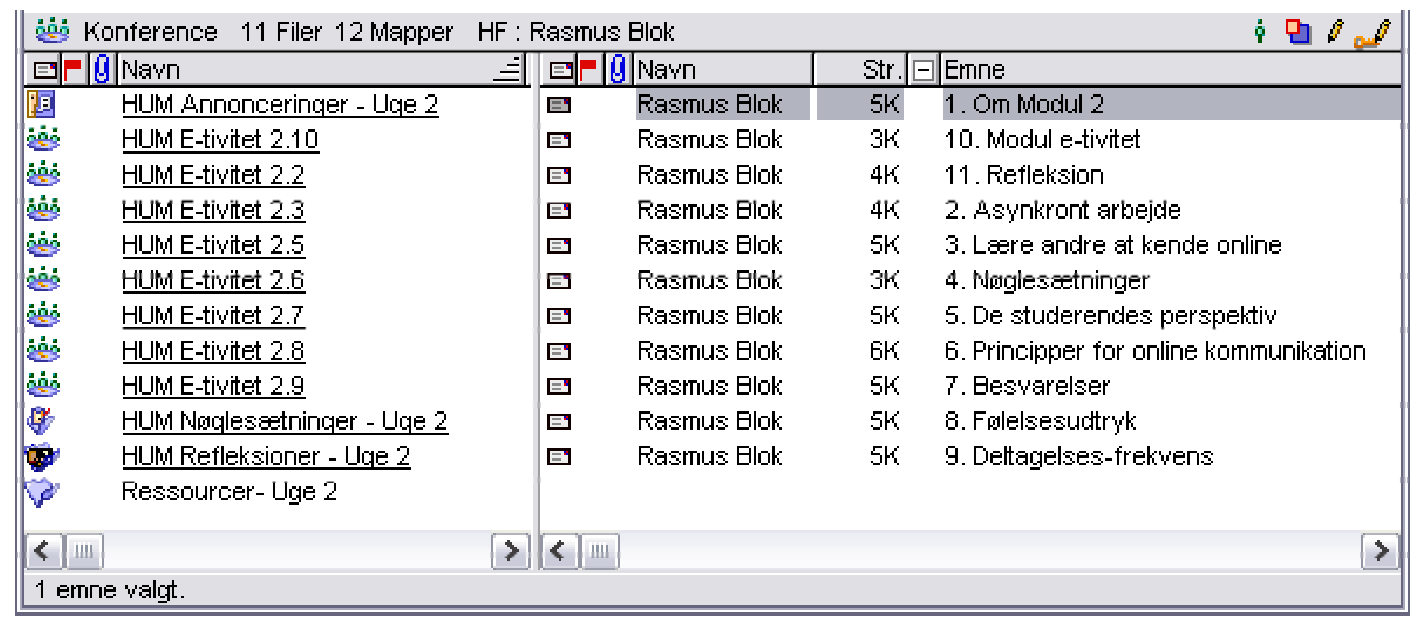

Figur 8. Her et kig ind i kursets Modul 2, der er struktureret således at roekken af opgaver (etiviteter-elektroniske aktiviteter) er listet til højre, mens konferencerne hvortil besvarelserne skal sendes er listet til venstre, sammen med konference for ressourcer og annonceringer.

Et konferencesystem eller internt netværk vil i en uddannelsesmæssig sammenhæng kunne være en vigtig faktor i forbedringen af studierne, studiemiljøet og det institutionelle arbejde. Ligeledes vil det kunne muliggøre nye former for kommunikation og arbejde, for derigennem at bidrage til den konstante udvikling af fagligheder, pædagogik og identitet. Endelig betyder brugen af konferencesystemet bredt på uddannelsesinstitutionen, ud over e-læringen, en bedre integration af e-læringen for den enkelte studerende og ansatte, og en bedre ressourceudnyttelse for uddannelsesinstitutionen. 


\section{Konferencerne}

Ud over at danne rammerne for e-læringen kan e-læringssoftwaren på uddannelsesinstitutionen eksempelvis også benyttes som containere og informationskanaler for:

- Indkaldelser og referater af div. møder

- Eksamenstil-/afmelding og eksamensresultater

- Regnskaber

- Links

- Regler og studieordninger

- Læse- og lokaleplaner

- Studievejledning

- Institutionel opslagstavle

- Div. udvalg, fx samarbejdsudvalg, IT-udvalg, fagudvalg mv.

- Adresser, telefonlister mm.

- Fagudvikling

- Kurser mm.

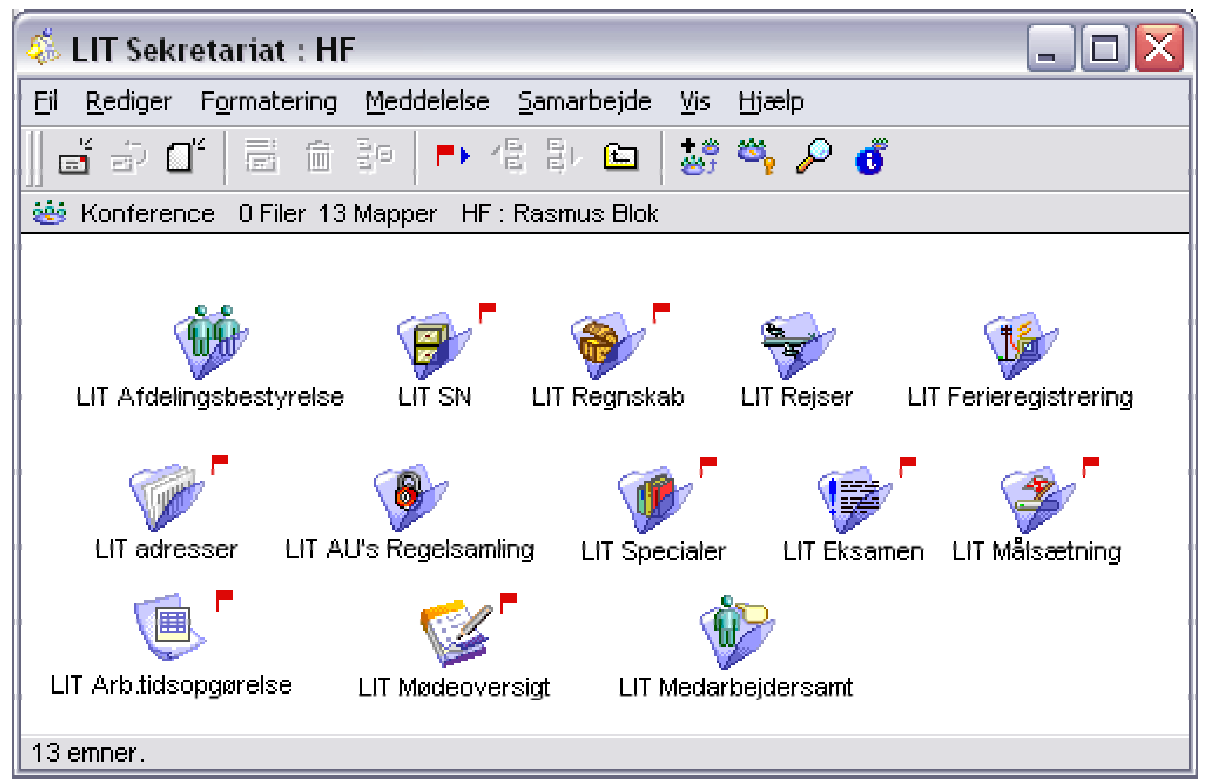

Figur 9. Her ses som eksempel et udsnit af Afd. for Litteraturhistories 'virtuelle sekretariat' $i$ FirstClass, hvor en helt rakke funktioner og oversigter og arkiver er tilgangelig for den enkelte underviser og ansatte.

Der findes selvfølgelig en helt række andre formål som konferencerne kan være til gavn for, ligesom man kan have underkonferencer og gøre dem til genstand for begrænset adgang.

Nogle har de studerende, eller grupper af studerende kun adgang til, nogle har alle adgang til, mens andre kun er for underviserne eller de ansatte, og atter nogle kun for få personer. Brugen og formålene afhænger jo af uddannelsesinstitutionens karakter, rammer og sammensætning. Formålet er at konferencerne i denne sammenhæng kan fungere som beholdere af information, som kan gøres tilgængeligt på kryds og tværs af uddannelsesinstitutionen, mens den samtidig altid er tilgængelig og centralt lagret.

\section{Kalendere}

Også kalenderen eller kalenderne kan benyttes i forskellige sammenhænge, alt afhængigt af, om de indgår i administrationen eller undervisningen. Med den private kalender kan man naturligvis holde styr på egne aftaler og evt. opgaver. Mange kalendere er udstyret med en hu- 
skeliste. I mange systemer kan man desuden vælge at give andre personer eller grupper adgang til sin kalender, hvor man så kan bestemme, hvilke oplysninger de kan se, eller på hvilket niveau de kan se dem. Man kan også give rettigheder til, at andre kan 'poste' møder i ens kalender. Det kan fx være nyttigt for sekretærer eller for administratorer, som arrangerer møder for mange på samme tid.

Den fælles kalender kan sættes op til en bestemt gruppe eller omhandle et bestemt emne, og brugerne kan gives visse specificerede rettigheder i forhold til at plotte informationer ind og slette dem igen. Den fælles kalenderfunktion kan bruges i mange sammenhænge og er naturligvis god til organisering af forskellige funktioner. Fx til angivelse af:

- Ansattes ferie

- Seminarer, konferencer o. lign.

- Fravær, rejse og sygdom blandt de ansatte

- Booking af lokaler/udstyr m.m.

- Vejlednings-/træffetider

- Fælles møder

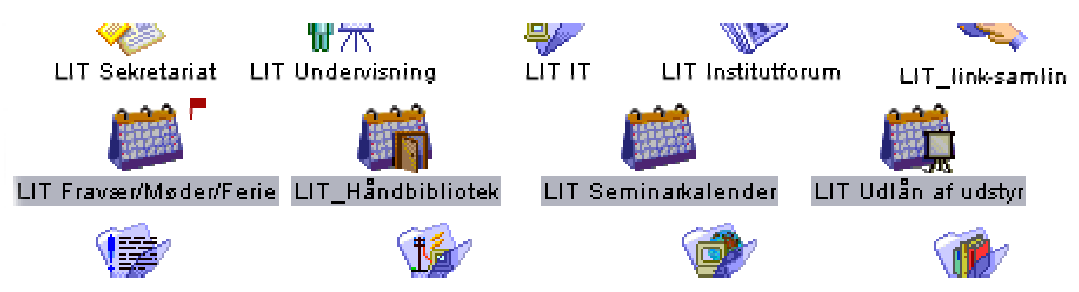

Figur 10. Her et udsnit af forskellige falleskalendere, hvis funktion fremgår af deres betegnelser.

\section{Mailbox}

De fleste konferencesystemer indeholder en mailfunktion, der spejler de fleste andre almindelige mailsystemer. Her kan man sende post både internt og eksternt, og hvor den interne brug ofte er lettet således, at man i stedet for at benytte deres eksterne email-adresse, kan sende direkte til brugerens navn eller bruger-id. Der er ofte også mulighed for at oprette adressekartotek, adresselister og postlister, som kan deles med andre indenfor systemet. Endelig har de fleste konferencesystemer den fordel, at den kan tilbyde brugeren en historik over intern post. Dvs. at der kan holdes styr på hvem og hvornår ens direkte mails eller meddelelser i konferencerne er blevet læst, videresendt, besvaret mv. Nogle systemer tillader også brugeren at trække sine e-mails eller konferencemeddelelser tilbage, hvis de endnu ikke er læst, fx for at rette fejl eller lignende.

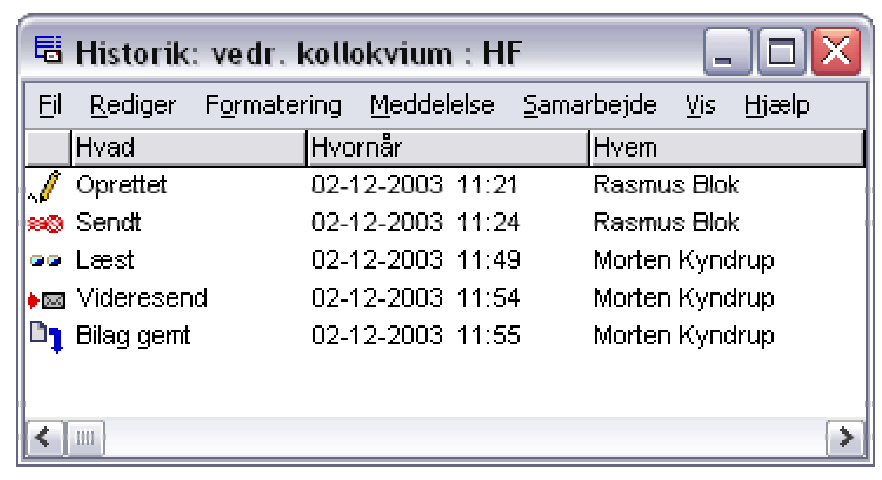

Figur 11. Her ses historikken af en meddelelse sendt af undertegnede til Morten Kyndrup. 
Brugen af de integrerede e-mailsystem vil alt andet lige være nemmere for de studerende, der modtager undervisning gennem e-læring. Det betyder færre skift mellem IKT-systemer og vil i højere grad betyde en integration af e-læringen med anden kommunikation på uddannelsesinstitutionen og selvfølgelig også med anden kommunikation i øvrigt. Ofte vil brugen af email-funktionen, som er den mest basale og derfor kendt af de fleste studerende, være en let indgang til at benytte øvrige funktioner i konference-softwaren.

\section{Chat}

Mange nye og opdaterede konferencesystemer tilbyder muligheden for chat. Chat er kendt og brugt på især Internettet, og betegner en online skriftlig konversation mellem to eller flere parter. Chat kan være baseret på et bestemt emne, der diskuteres, eller kan blot være løs og 'samtalepræget'.i sine rammer. Man skelner ofte mellem to typer chat - den åbne og den lukkede form. Den åbne chat er som regel den emnebestemte, og alle med interesse i netop dette emne kan logge på og deltage i diskussionen. Den lukkede chat kan være en samtale mellem få parter, der er inviteret til at deltage, eller et mindre diskussionsforum af inviterede, hvor et konkret emne er til debat. Oftest har alle med adgang til konferencesystemet, mulighed for selv at oprette en lukket chat og invitere andre til at deltage $\mathrm{i}$ den.

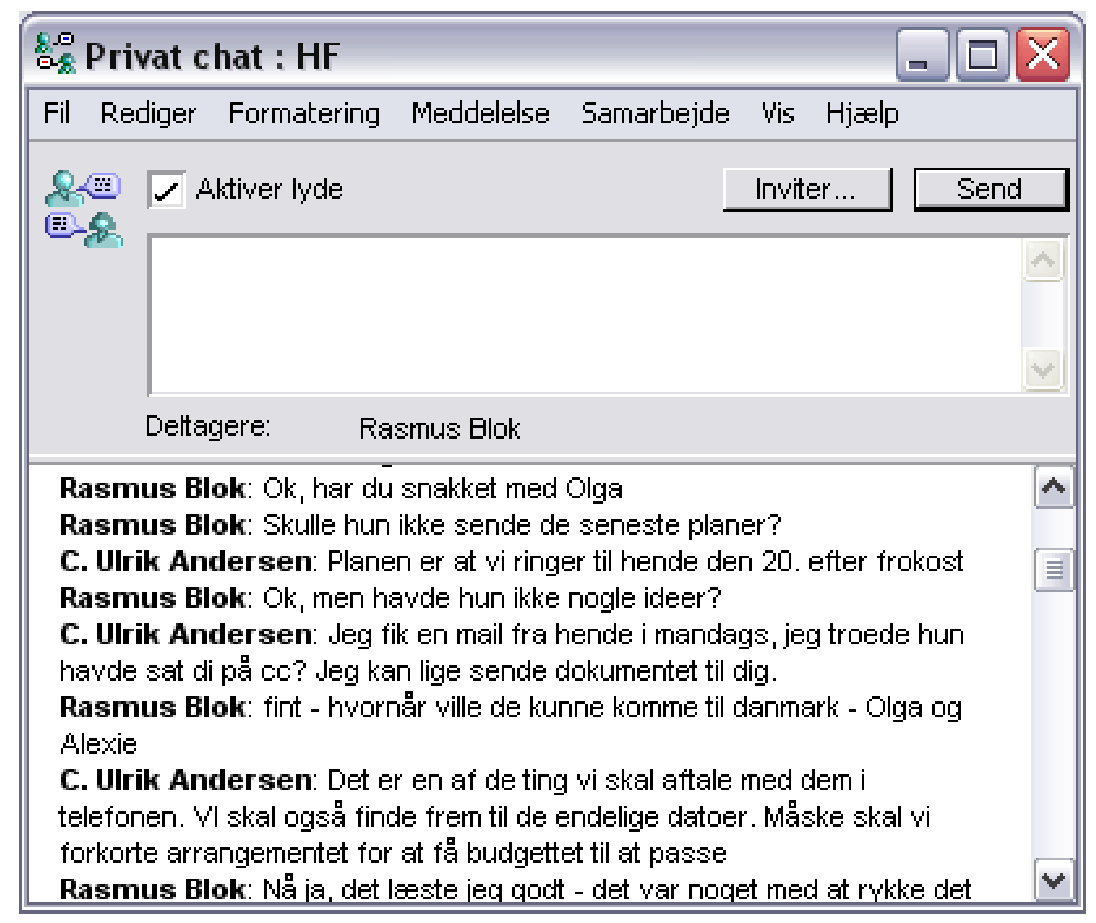

Figur 12. Her et eksempel på brug af privat chat-funktion mellem to personer. Parterne har mulighed for at invitere andre med $i$ chatten, så flere kan deltage på samme tid.

Chatten kan være en kærkommen mulighed, der bryder konferencesystemets asynkrone natur, for at få en synkron samtale eller diskussion med nogle andre studerende. Enten gennem chats om faglige emner, eller som private samtaler. Fx er det en god mulighed for de studerende til at få kontakt andre studiefæller, som også er online på samme tid, evt. til at afklare akutte spørgsmål o lign. Særligt hvis der er tale om sene aftentimer eller uden for alm. arbejds- og studietid. Man kan også oprette åbne chats, som kan supplere kaffestuerne og give den løse snak et lidt mere 'live' præg. 


\section{E-læringens perspektiver for uddannelsesinstitutionerne}

Hvor brugen af e-læring for mange uddannelsesinstitutioner i første omgang ofte iværksættes på baggrund af praktiske og forsøgsvise omstændigheder for enkelte grupper af studerende og udelukkende i undervisningsøjemed, er det vigtigt for uddannelsesinstitutionen at være åben over for de potentialer som e-læringen og dens teknologi kan have på rækken af aktiviteter og arbejdsgange, som foregår på institutionen.

Det primære mål med implementering og brug af e-læring og digitale konference-software kan ultimativt blive en forbedring af hele undervisningssituationen og dens organisering, involverende alle institutionens parter og ansatte. Hermed kan undervisningen bringes på højde med en række af de krav både de studerende selv, underviserne, efterfølgende uddannelsesinstitutioner og det aftagende private og offentlige erhvervsliv stiller til uddannede i dag. Ligeledes kan institutionen benytte teknikken til at få omstruktureret sine arbejdsgange og arbejde mod en mere åben brug af IKT til gavn for ansatte og studerende og i tråd med de tendenser som hersker indenfor moderne arbejdsorganisering og offentlig forvaltning.

Med disse mere generelle betragtninger over e-læringsteknologien og dens muligheder og perspektiver, håber jeg at have tilvejebragt indsigt $i$, at man ved brug af e-læring kan åbne mulighed for, at:

- undervisningen kan animere til mere aktiv læring og engagement

- "tilstedeværelsen" af den studerende i højere grad kan ændres til interaktion

- den studerende kan opnå større ansvar for egen læring

- undervisningen kan bringes i tættere og mere relevant sammenhæng med gængse eksamensformer (via funderingen på skriftlighed)

- de studerendes kompetencer kan styrkes indenfor IKT, samarbejde og skriftlig formidling

- undervisningen kan gøres mere dynamisk og fleksibel til gavn for læringen, den studerende og underviseren

- undervisningen kan bringes i bedre pædagogisk overensstemmelse med de krav og udfordringer, det aftagende samfund stiller uddannede overfor

- styrke det samlede lærings- og undervisningsmiljø for studerende og ansatte

- forbedre arbejdsgange og skabe mere åbenhed i organiseringen

Og netop af disse grunde kan det være en god idé på et eller andet niveau, at påbegynde benyttelsen af e-læring i undervisningen - også selvom det måske ved første øjekast synes krævende! Det er således min opfattelse, at man allerede ved et forholdsvis lavt brugsniveau af elæring og digitale konferencer i undervisningen kan opnå anselige fordele.

Slutteligt vil omlægningen af undervisningen, samt opstarten og implementering af digitale konference altid koste en del sved og tårer arbejdsmæssigt, ligesom enhver anden implementering eller omlægning af arbejdsprocesser. Meget af sådant begyndende arbejde drives ofte af ildsjæle, som typisk har en personlig interesse og flair for det, og som derfor ofte virker usynlig for andre, inklusiv undervisningsinstitutionens ledelse. Min erfaring fortæller, at det er vigtigt for hele implementeringsprocessen at et sådant arbejde synliggøres gennem anerkendelse og normering. Det skaber det bedste grundlag for en god og stabil proces.

Brugen af e-læring og konference-software i undervisningen - uanset ambitionsniveau - kan ikke indføres, uden at det kræver en vis grad af investeringer og ændringer for hele rækken af parter involveret i undervisningen - fra ledelse til studerende. Dette skal selvfølgelig understreges fordi mangel på fokusering af disse ændringer kan skabe en række problemer og van- 
skeligheder, som besværliggør en implementering. Omvendt bør det ligeledes understreges, at gør man sig umage med at medtænke disse ændringer og rækkevidden deraf for alle parter, så er der god grund til at tro, at processen vil foregå engageret og uden alvorlige problemer. Implementering af e-læring og digitale konferencer er i et overordnet syn blot et led i en udviklingsproces, som alle uddannelsesinstitutioner bør tage del i. 